\title{
Chemotherapy Increases Stroke: Fact or Fiction?
}

\author{
Yohei Hisada ${ }^{1}$ Steven Philip Grover ${ }^{1} \quad$ Nigel Mackman ${ }^{1}$
}

\author{
${ }^{1}$ Division of Hematology/Oncology, Department of Medicine, UNC \\ Blood Research Center, University of North Carolina at Chapel Hill, \\ Chapel Hill, North Carolina, United States \\ Thromb Haemost 2020;120:534-536.
}

Address for correspondence Nigel Mackman, PhD, Division of Hematology/Oncology, University of North Carolina at Chapel Hill, 8004B, Mary Ellen Jones Building, 116 Manning Drive, CB 7035, Chapel Hill, NC 27599-7035, United States

(e-mail: nmackman@med.unc.edu).
Cancer is associated with an increased risk of thromboembolic events (TEEs). ${ }^{1-6}$ The underlying mechanisms of cancer-associated thrombosis are complex because many factors can contribute to TEE, including site and stage of the cancer, type of treatment, such as chemotherapy, and patient characteristics, such as age (- Fig. 1). ${ }^{7}$ Cancer type-specific mechanisms include tissue factor-positive extracellular vesicles for pancreatic cancer and podoplanin expression for brain cancer. $^{8-10}$ Therefore, it is difficult to determine the relative contribution of these different factors to thrombosis. In this issue of Thrombosis and Haemostasis, Kitano et al analyzed the effect of chemotherapy on stroke in cancer patients. ${ }^{11}$

The rate of venous thromboembolism (VTE) (1-19\%) in cancer is much higher than the rate of arterial thromboembolism (ATE) $(0-5 \%){ }^{1-5}$ One study found that the 6-month cumulative incidence of ATE (composite of myocardial infarction and ischemic stroke) and ischemic stroke was significantly increased in cancer patients compared with controls patients (ATE 4.7\% vs. 2.2\%; ischemic stroke 3.0\% vs. $1.6 \%) .{ }^{12}$ The risk of ATE in cancer patients was affected by cancer stage and to a lesser extent by cancer type (with the highest rate for lung cancer). Another study also found an increase in the 3-month cumulative incidence of ischemic stroke was higher in patients with cancer compared to controls and affected by cancer type (lung $5.1 \%$, pancreatic $3.4 \%$, colorectal $3.3 \%$, breast $1.5 \%$, and prostate $1.2 \%) .{ }^{13}$ Cerebral infarction was also observed in nonsmall cell lung cancer patients $(2.9 \%)$ with those with brain metastasis having the highest rate (6.3\%). ${ }^{14}$ Gastric cancer patients are also prone to ischemic stroke after surgery. ${ }^{15}$ Stroke patients with cancer have a worse prognosis compared with stroke patients without cancer. ${ }^{14,16,17}$

Numerous chemotherapeutic agents are used to treat various forms of cancer that include untargeted "conventional" agents, such as cisplatin, and targeted "unconventional" agents, such as tyrosine kinase inhibitors. Cisplatin-based chemotherapy was shown to be associated with a high rate of TEE (18.1\%) in 932 patients with a variety of cancers, but

most of these events were VTEs with only $1.5 \%$ of the events being ATEs. ${ }^{18}$ Another study with bladder cancer patients found that patients treated with platinum-based chemotherapy had a significantly higher rate of TEE compared with patients who did not receive chemotherapy (19.5\% vs. 11.6\%). ${ }^{19}$ Several studies have investigated the effect of both conventional and nonconventional chemotherapy on stroke in cancer patients ( - Table $\mathbf{1}$ ). One study investigated the effect of chemotherapy and/or radiotherapy on stroke in head and neck cancer patients and concluded that patients $<55$ years of age but not patients $\geq 55$ years of age had an increased risk of stroke with chemotherapy, radiotherapy, or both compared with patients with surgery alone. ${ }^{20}$ Another study concluded that chemotherapy, especially platinum-based regimes, was an independent risk factor for stroke in ovarian cancer patients. ${ }^{21}$ In contrast, chemotherapy (cisplatin or carboplatin) did not increase the risk of stroke in patients with stage II to III bladder cancer. ${ }^{19}$ Other studies have investigated the effect of nonconventional chemotherapeutic agents on stroke. For instance, the vascular endothelial growth factor inhibitor bevacizumab increased the overall relative risk of cerebrovascular events in patients with a variety of cancers by $3.28 .{ }^{22}$ In addition, use of the vascular endothelial growth factor receptor tyrosine kinase inhibitors sunitinib and sorafenib was associated with an increase in stroke in patients with renal cell carcinoma. $^{23}$

Kitano et $\mathrm{al}^{11}$ analyzed the effect of chemotherapy on stroke by comparing the rates in patients with $(n=5,887)$ or without $(n=13,119)$ chemotherapy. The study included a variety of cancer types and both conventional (9-60\% of patients) and nonconventional (6-14\% of patients) chemotherapeutic agents. Cancer patients who received chemotherapy had a higher rate of stroke $(0.75 \%)$ compared with patients who did not receive chemotherapy (0.39\%). KaplanMeier curve analysis of the data indicated a significant difference between the two groups (hazard ratio 1.84; 95\% confidence interval 1.23-2.75). Importantly, however, there was no significant difference after adjustment for cancer

(c) 2020 Georg Thieme Verlag KG Stuttgart · New York
DOI https://doi.org/ 10.1055/s-0040-1708550. ISSN 0340-6245. 


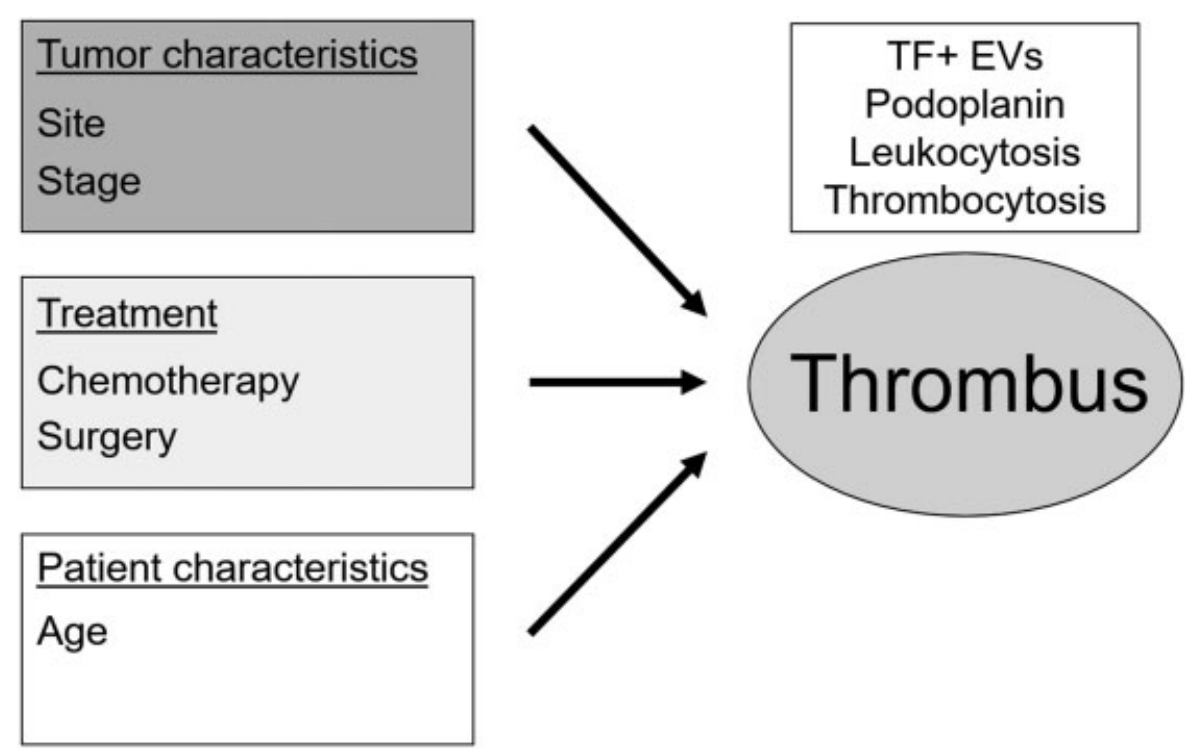

Fig. 1 Risk factors for cancer-associated thrombosis. Risk factors for thrombosis in cancer patients include tumor characteristics, treatment, and patient characteristics. Tissue factor (TF)-positive extracellular vesicles (EV), podoplanin, leukocytosis, and thrombocytosis may enhance thrombosis in cancer patients.

Table 1 Studies investigating the association between chemotherapy and stroke in cancer patients

\begin{tabular}{|c|c|c|c|c|c|c|c|c|}
\hline Study & $\begin{array}{l}\text { Cancer } \\
\text { type }\end{array}$ & $\begin{array}{l}\text { Chemotherapy } \\
\text { type }\end{array}$ & $\begin{array}{l}\text { Total } \\
\text { no. of } \\
\text { patients }\end{array}$ & $\begin{array}{l}\text { No. of patients } \\
\text { received } \\
\text { chemotherapy } \\
\text { (\%) }\end{array}$ & $\begin{array}{l}\text { No. of stroke } \\
\text { in patients } \\
\text { without } \\
\text { chemotherapy } \\
\text { (\%) }\end{array}$ & $\begin{array}{l}\text { No. of stroke } \\
\text { in patients } \\
\text { received } \\
\text { chemotherapy } \\
\text { (\%) }\end{array}$ & $\begin{array}{l}\text { Association } \\
\text { between } \\
\text { chemotherapy } \\
\text { and stroke }\end{array}$ & Ref \\
\hline $\begin{array}{l}\text { Kuan } \\
\text { et al }\end{array}$ & Ovarian & Various types & 8,810 & $6,590(74.8)$ & $\mathrm{N} / \mathrm{A}$ & $\mathrm{N} / \mathrm{A}$ & Yes & 21 \\
\hline $\begin{array}{l}\text { Huang } \\
\text { et al }\end{array}$ & $\begin{array}{l}\text { Head } \\
\text { and } \\
\text { neck }\end{array}$ & Platinum & 10,172 & $\begin{array}{l}663 \text { (under the } \\
\text { age of 55) (6.5) }\end{array}$ & $\begin{array}{l}42 \text { (surgery } \\
\text { only) (2.5) }\end{array}$ & $24(3.6)$ & Yes & 20 \\
\hline $\begin{array}{l}\text { Gupta } \\
\text { et al }\end{array}$ & Bladder & Platinum & 5,057 & $1,079(21.3)$ & $216(5.4)$ & $54(5.0)$ & No & 19 \\
\hline $\begin{array}{l}\text { Zuo } \\
\text { et al }\end{array}$ & $\begin{array}{l}\text { Various } \\
\text { types }\end{array}$ & Bevacizumab & 12,705 & $6,421(50.5)$ & $14(0.2)$ & $59(0.9)$ & Yes & 22 \\
\hline $\begin{array}{l}\text { Jang } \\
\text { et al }\end{array}$ & Kidney & $\begin{array}{l}\text { Tyrosine kinase } \\
\text { inhibitors }\end{array}$ & 1,458 & $670(46.0)$ & $\mathrm{N} / \mathrm{A}$ & $24(3.6)$ & Yes & 23 \\
\hline $\begin{array}{l}\text { Kitano } \\
\text { et al }\end{array}$ & $\begin{array}{l}\text { Various } \\
\text { types }\end{array}$ & Various types & 19,007 & $5,887(31)$ & $51(0.39)$ & $44(0.75)$ & $\mathrm{Yes} / \mathrm{No}^{\mathrm{a}}$ & 11 \\
\hline
\end{tabular}

${ }^{\mathrm{a} T h e}$ association was not significant after adjusting for cancer status.

status (cancer stage and site). In addition, chemotherapy was also not associated with increased stroke after adjustment for cancer status in either a stratified Cox regression model or a time-dependent covariate Cox regression model. Similarly, subanalysis indicated platinum-based chemotherapy did not increase stroke.

The strengths of the study by Kitano et al $^{11}$ are its size and the adjustment for cancer status and age. However, there are some limitations. For instance, the study includes a variety of cancer types, which are known to have a different incidence of stroke, and various types of conventional and nonconventional chemotherapies, which have a different impact on the risk of stroke. The authors did not perform subanalysis of chemotherapy other than platinum-based regimes and did not perform subanalysis of cancer type because the number of events in each cancer type was too small.

In conclusion, Kitano et al concluded that chemotherapy is not associated with increased risk of stroke in a general cancer patient population after adjustment for cancer status. However, future studies are needed to investigate the effect of specific classes of agents in specific cancer types.

Conflict of Interest

None declared. 


\section{References}

1 Di Nisio M, Ferrante N, Feragalli B, et al. Arterial thrombosis in ambulatory cancer patients treated with chemotherapy. Thromb Res 2011;127(04):382-383

2 Timp JF, Braekkan SK, Versteeg HH, Cannegieter SC. Epidemiology of cancer-associated venous thrombosis. Blood 2013;122(10): $1712-1723$

3 Grilz E, Königsbrügge O, Posch F, et al. Frequency, risk factors, and impact on mortality of arterial thromboembolism in patients with cancer. Haematologica 2018;103(09):1549-1556

4 Aronson D, Brenner B. Arterial thrombosis and cancer. Thromb Res 2018;164(Suppl 1):S23-S28

5 Khorana AA, Dalal M, Lin J, Connolly GC. Incidence and predictors of venous thromboembolism (VTE) among ambulatory high-risk cancer patients undergoing chemotherapy in the United States. Cancer 2013;119(03):648-655

6 Pelland-Marcotte MC, Tole S, Pechlivanoglou P, Brandão LR. Effectiveness and safety of primary thromboprophylaxis in children with cancer: a systematic review of the literature and network meta-analysis. Thromb Haemost 2019;119(12): 2034-2042

7 Hisada Y, Geddings JE, Ay C, Mackman N. Venous thrombosis and cancer: from mouse models to clinical trials. J Thromb Haemost 2015;13(08):1372-1382

8 Hisada Y, Mackman N. Cancer-associated pathways and biomarkers of venous thrombosis. Blood 2017;130(13):1499-1506

9 Geddings JE, Mackman N. Tumor-derived tissue factor-positive microparticles and venous thrombosis in cancer patients. Blood 2013;122(11):1873-1880

10 Mir Seyed Nazari P, Riedl J, Pabinger I, Ay C. The role of podoplanin in cancer-associated thrombosis. Thromb Res 2018;164(Suppl 1): S34-S39

11 Kitano T, Sasaki T, Gon Y, et al. The effect of chemotherapy on stroke risk in cancer patients. Thromb Haemost 2020;120(04): 714-723
12 Navi BB, Reiner AS, Kamel H, et al. Risk of arterial thromboembolism in patients with cancer. J Am Coll Cardiol 2017;70(08):926-938

13 Navi BB, Reiner AS, Kamel H, et al. Association between incident cancer and subsequent stroke. Ann Neurol 2015;77(02):291-300

14 Kato M, Shukuya T, Mori K, et al. Cerebral infarction in advanced non-small cell lung cancer: a case control study. BMC Cancer 2016;16:203

15 Kuan AS, Chen SC, Yeh CM, et al. Risk of ischemic stroke in patients with gastric cancer: a nationwide population-based cohort study. Medicine (Baltimore) 2015;94(37):e1336

16 Murthy SB, Shastri A, Merkler AE, et al. Intracerebral hemorrhage outcomes in patients with systemic cancer. J Stroke Cerebrovasc Dis 2016;25(12):2918-2924

17 Gon Y, Todo K, Mochizuki H, Sakaguchi M. Cancer is an independent predictor of poor outcomes in patients following intracerebral hemorrhage. Eur J Neurol 2018;25(01):128-134

18 Moore RA, Adel N, Riedel E, et al. High incidence of thromboembolic events in patients treated with cisplatin-based chemotherapy: a large retrospective analysis. J Clin Oncol 2011;29(25): 3466-3473

19 Gupta A, Long JB, Chen J, Gross CP, Feldman DR, Steingart RM. Risk of vascular toxicity with platinum based chemotherapy in elderly patients with bladder cancer. J Urol 2016;195(01):33-40

20 Huang YS, Lee CC, Chang TS, et al. Increased risk of stroke in young head and neck cancer patients treated with radiotherapy or chemotherapy. Oral Oncol 2011;47(11):1092-1097

21 Kuan AS, Teng CJ, Wu HH, et al. Risk of ischemic stroke in patients with ovarian cancer: a nationwide population-based study. BMC Med 2014;12:53

22 Zuo PY, Chen XL, Liu YW, Xiao CL, Liu CY. Increased risk of cerebrovascular events in patients with cancer treated with bevacizumab: a meta-analysis. PLoS One 2014;9(07):e102484

23 Jang S, Zheng C, Tsai HT, et al. Cardiovascular toxicity after antiangiogenic therapy in persons older than 65 years with advanced renal cell carcinoma. Cancer 2016;122(01):124-130 